\title{
LAND USE EFFECT ON NITROGEN AND PHOSPHORUS FLUXES INTO AND FROM SOIL
}

\author{
H. Barış TECIMEN1,2 \\ ${ }^{1}$ Istanbul University, Faculty of Forestry, Soil Science and Ecology Dept. 34473, Bahçeköy - İstanbul - Türkiye \\ 2Indian River Research and Education Center, Institute of Food and Agriculture Science, University of Florida, \\ 34945, 2219 South Rock Road, Fort Pierce, FL-USA \\ hbarist@gmail.com
}

\begin{abstract}
Land use is recently being taken in consider among ecologists thus the global imbalances of biological and mineral aspects on earth raised and have been retaining since last century with births of undescribed and introduced problematic issues. One of the most threatening effect of those global problems is extinction of food and water resources. Soil utilization, land management practices, source (land properties containing above and below ground resources) based features are the main marks of land use issue. Within this study, (i) what extend does the land use change effect the nitrogen content in soil and freshwater systems, (ii) microbial agents' effects on phosphorus sources, (iii) environmental threatens and anxieties of improper land use are questioned. The results revealed that, both nitrogen and phosphorus elemental cycles are interrupted by abrupt changes at land uses, while, sustainability of resource management and controls at microbial level might highly be subsidiary to solution of land use sourced degradations.
\end{abstract}

Keywords: Land use, nitrogen, phosphorus, soil.

\section{Özet}

Küresel ölçekte meydana gelen biyolojik dengenin bozulması ve madde dolaşımındaki anormallikler ve son yüzyılda rastlanan yeni ve tanımlanamayan problemlerden ötürü, arazi kullanımı, ekolojiyle ilgilenen bilim insanları tarafından mercek altına alınmaya başlamıştır. Bu küresel problemler arasındaki en büyük problem, su ve besin kaynaklarının yok olmasıdır. Toprağın kullanımı, arazi yönetimi uygulamaları, toprak altı ve toprak üstü özelliklerinden oluşan arazi kaynağı, arazi kullanımının en önemli hususlarını oluşturmaktadır. Bu çalışmada, (i) arazi kullanımının toprak ve tatlısulardaki azot içeriğine etkileri, (ii) mikroorganizmaları fosfor kaynakları üzerine etkileri, (iii) yanlış arazi kullanımının çevre için doğurduğu tehditler ve stresler sorgulanmıştır. Çalışma sonucunda, azot ve fosfor döngülerinin, arazi kullanımı değişiminden dolayı şiddetli bir şekilde sekteye uğradığı ve mikroorganizma düzeyinde yürütülecek olan sürdürülebilir kaynak yönetimi uygulamaları, arazi kullanımından ve/veya arazi kullanımı değişiminden kaynaklanan sorunların çözümüne yardımcı olacağı anlaşılmaktadır.

Anahtar kelimeler: Arazi kullanımı, azot, fosfor, toprak.

\section{INTRODUCTION}

Nitrogen and phosphorus are crucial elements for plant nutrition and also highly used by fertilizers at agricultural fields. Land use change in advantage of agricultural lands, conversion of forest lands and wetlands to agricultural lands causes higher fertilizer receiving in soil. Growth of population resulted to increased food source creating an impulse to over loading soil with fertilizers. After nutrient elements absorbed by plants at a sufficient amount, the excess of the labile macronutrients move from soil to freshwater systems by either underground crack structure or surface water flow. Pollution of freshwater by eutrophication, decrease in oxygen amount in water, extinction of wetlands creates strong influence on global climate. This is supported by negative feedback cycle in the sequence of disappearance of wetlands increased temperature - temperature induced 
evaporation - loss of wetland water (Lloret et al. 2008). Besides wetlands are both highly sensitive to global climate change and have a regulatory role on climate change. Since floodplains, mangroves, seagrasses, saltmarshes, arctic wetlands, peatlands, freshwater marshes and forests are very diverse habitats, with different stressors and hence different management and restoration techniques are needed (Erwin 2009) in terms of both protection from pollutants and itself freshwater source. The symptoms of eutrophication, such as noxious and harmful algal blooms, reduced water quality, loss of habitat and natural resources, and severity of hypoxia (oxygen depletion) and its extent in estuaries and coastal waters will increase and global climate changes will likely result in higher water temperatures, stronger stratification, and increased inflows of freshwater and nutrients to coastal waters in many areas of the globe (Rabalais et al. 2009).

Land use is under the influences of actual utilization status of a land (land use type such as forest, agriculture or pasture), geographical position, microclimate caused by land, exposed climatic effects, change of function of a land and further management strategies. Thus the effects of land use on nitrogen and phosphorus elements should be taken in considered from the point of this view. Limitations and obligations imposed by the governmental agents suppress the use of fertilizer or pesticide use to prevent pollutant effects the natural resources. The most prominent outcomes of land use change or land use management type consist from artificial effects by farmers as chemical substrates or remaining the land as a pasture or forest land with its natural but more complex relations. Though, unintended effects of nitrogen and phosphorus fertilizers' soluble or dissolved compounds create significant changes at worldwide level.

Thus, in this article the fate of derivatives and by products of excess nitrogen and phosphorus caused from land use and management strategies have been criticized. The issues questioned are; (i) what extend does the land use change effect the nitrogen content in soil and freshwater systems, (ii) microbial agents' effects on phosphorus sources, (iii) environmental threatens and anxieties of improper land use.

\section{LAND USE DISTRIBUTION IN THE WORLD}

Two major land use types consist from agricultural lands and forest lands, whereas account up to $65 \%$ of global terrestrial ecosystems and the rest of the terrains show a variety of land uses such as; wetlands, deserts, prairies, tundra, savannas, pasturelands and glacials. The highest agricultural activities approximately $30 \%$ of world's total surface area is being conducted at temperate, tropical and subtropical regions of the world (Fig. 1 and 2).

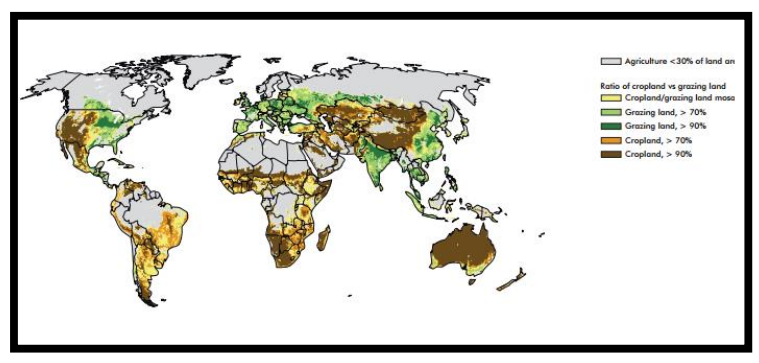

Figure 1. Wordlwide distribution of agricultural lands. (Center for Sustainability and the Global Environment (SAGE) at University of Wisconsin-Madison. 2003)

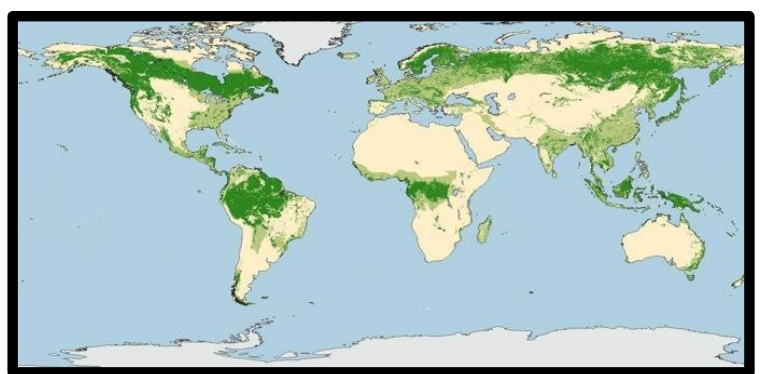

Figure 2. Forestlands distribution in the world (https://myweb.rollins.edu/jsiry/WhereTheWor ld \%20are .html)

However, the conversion of land use under the forces of urbanization, agricultural aims and other socio-economic factors have influent impact on natural resources. The main conclusion of land use is deterioration of a given land itself either irreversibly or requiring a long term and high cost remediation - rehabilitation efforts. The side effects, which sometimes take place at the first rank in terms of global effects, are climate change, destruction of ecosystem services, decreased biodiversity, interruption of nutrient cycles and energy flows. Whatever the reason causes to land use change, a conversion reasoned to a natural habitat deterioration has recently been perceived as a multidimensional problem for all stakeholders of a land.

Both over and under acquisition and sequestration of nitrogen and phosphorus are causing serious problems in the managed and natural ecosystems, revealing the signs of either soil and water pollution or nutrient deficiency. 
Plant growth, microbial processes and subsequently the further ecosystem services are all negatively influenced. For a sustainable amount of product harvest from a given land requires renewably use of the resources. Once the ecosystem balance was disturbed and the resources were unconsciously consumed, the negative feedback loop accelerates the collapsing the system. Management and long term utilization of a land is highly dependent upon the nitrogen and phosphorus equilibrium settled in soil.

\section{HOW NITROGEN FLUX AND CYCLE IS INFLUENCED FROM LAND USE CHANGE}

One of the main nitrogen fixation to soil is done by free living bacteria and by the symbiotic bacteria living with legume plants. Agricultural lands differ from natural ecosystems from the aspects of nutrient input-output, soil treatments and irrigation which are also called subsidized ecosystems. While use of urea, ammonium, and nitrate forms of nitrogen containing fertilizers provide continuous nitrogen input to soil and plants, imbalances the nutrient budget and microbial community composition. Decrease in microbial population diversity reveals as a weakened soil health. Associative and free-living microorganisms may contribute to the nutrition of plants through a variety of mechanisms and as antagonists of root pathogens (Raaijmakers et al. 2009). Similar results were obtained at a study focused on land use change at sub-tropical region with conclusions of decreased $\mathrm{N}$ mineralization potential and microbial nitrogen content after conversion of a forest land to a savannah with perennial bushes but receiving higher radiation and subsequently harsher conditions for microorganisms (Jay et al. 2009). Alternately, the abandonment of agricultural lands to forest land caused to increases of $39 \%$ for $\mathrm{N}$ and $52 \%$ for $\mathrm{P}$. According to the same study nitrification was strongly influenced by land-use history, with highest rates in formerly cultivated sites and in contrast, soil net $\mathrm{N}$ mineralization and chloroform- $\mathrm{N}$ were more strongly influenced by present vegetation (Compton and Boone 2000). The obtained results had been laid upon historical manure inputs because of its possible impulse effect on decreasing soil C: $\mathrm{N}$ ratios and thus reducing nitrate immobilization in the mineral soil of cultivated sites.

Within the land use change the most obvious difference between the two land use types is the form of the vegetation. Thus, evaluation of a given land use change effect on nitrogen requests to be discussed in connection with vegetation form on the field. In the study by (Knops and Tilman 2000), they found that nitrogen in soil is influentially efficient on soil carbon and the content of nitrogen relies on atmospheric deposition and symbiotic nitrogen fixation by legumes while $C_{3}$ and $C_{4}$ grasses support mostly carbon accumulation.

While, historical background of a land use type mainly determinant on the current nutrient element pool status, the past perturbations of a soil biological composition and fluxes into and from the soil, from and to surrounding environments remains unknown within the myths enclosed in. Those requires long term periodical observations containing subsidiary parameters such as type of the manures applied, soil and vegetation treatments, irrigation methods and $\mathrm{pH}$ adjusting additions. Fresh water pollution from land use conversions are the end point of a land degradation and also revealing the most remarkable alert sign. Prior to water pollution (below or above ground water resources), the surficial soil properties are entirely degraded, and thereafter microbial population, elemental turnover cycles and eventually the productivity of soil are spoiled.

\section{PHOSPHORUS AVAILABILITY IN SOIL AND EFFECTS OF MICROBIAL AGENTS}

Soil type as well plays a key function on the pool and fluxes of phosphorus element (Djodjic et al. 2004) found relation between water leaching mechanism through the topsoil and subsoil among five different soil types. As well, according to the study by (Lilienfein et al. 2000) savannah fields with nutrient-poor oxisol soils with low $\mathrm{P}$ concentration $\mathrm{P}$ is strongly absorbed resulting in low plant-available $\mathrm{P}$ concentrations by high amount of hydrous oxides of Fe. Determination of excess phosphorus could have been revealed from the influxes from arable lands towards stream waters. While diffuse sources account to dominant annual load of phosphorus, point source (a certain fertilized field or a livestock farm) fluxes cause to daily fluctuation as a determinant source in terms of dissolved hydrolysable phosphorus, particulate phosphorus so the total phosphorus (approximately double the concentration than the other high agricultural intensity catchments) revealing that intensive 
cattle farming located in close proximity to the stream channel is a major source of organic and particulate N and P (Jarvie et al. 2010). Rapid urbanization and row crop increase were detected as the most notable changes in land use and land use practices among the land use types of abandoned diary, citrus plantation, commercial forestry, diary, field crop, ornamentals, residential areas at different densities, row crops and sod farming at Florida Okeechobee watershed (Hiscock et al. 2003).

Besides the mineral resource of phosphorus, organic form of the phosphorus is also an essential tract of elemental pool. As microbial biomass takes accounts to the main sink for organic P microorganisms are perceived higher value in terms of organic $\mathrm{P}$ pool with the evident of high microbial P-to-organic P ratios compared to significantly higher than those of microbial Cto-total $\mathrm{C}$ and microbial N-to-total $\mathrm{N}$, especially in the litter layers and forest mineral soil. The results indicate that continuous cultivation with little or no P input not only decreased the amount, but also influenced the structural composition and bioavailability of $\mathrm{P}$ in tropical soils (Solomon et al. 2002).

\section{LAND USE CONVERSION IMPACTS ON EARTH ENVIRONMENT}

Land use change of forests to agricultural lands is the most widespread convention on the earth with dramatic changes of soil quality, soil productivity, vegetation type, carbon sequestration, microbial community composition change and decrease at microbial biomass. Those alterations have crucial impacts on global nitrogen cycle with subsequent effects of climate change and degradation of biodiversity. Phosphorus leaching as a result of reduced retention and sequestration causes higher accumulation at fresh water systems.

On the other hand, abandonment of agricultural lands, creates abrupt flushes of labile but not absorbed by agricultural plants to freshwater sources. Obviously, the agricultural lands as the cultivated ecosystems for highest production in the shortest period received the supreme amount of fertilizers. Within the fertilizers, pesticides, hormones, growth promoters and various protective but environmentally hazardous chemicals are used at open system fields or in greenhouses. Even though the retained molecules are decomposed to some extend revealing chelated insoluble macromolecules, the decomposition products still carries polluting effect with phosphorus roots (Egan et al. 1963; Cook et al. 1978).

\section{DISCUSSION AND CONCLUSION}

Eutrophication of wetlands resulting from phosphorus $(\mathrm{P})$ and nitrogen $(\mathrm{N})$ enrichment has been perceived as a global problem, leading to reduction of water quality for drinking and also diminished aquatic biodiversity (Jarvie et al. 2010). While land-use change is to increase the local capacity of lands to support the human enterprise many land-use practices instead reduce this capacity such as deleterious local and regional effects of deforestation for pastures, for example, include erosion of soils, reduced rainfall, reduced capacity of soils to hold water, increased frequency and severity (Houghton 2003). The effects of intensive agricultural practices, such as cereal production, forage maize, potatoes, intensive dairy and outdoor pigs are generally regarded as 'high risk' for $\mathrm{P}$ and $\mathrm{N}$ loss to rivers, because they are either regularly over-fertilized, recycle large amounts of manure, or are highly vulnerable to soil erosion may be exacerbated where 'high-risk' agricultural practices are located in close proximity (Jarvie 2010).

In conclusion, land use change has a global effect in terms of biodiversity, nutrient cycles, continuity of life in water systems and ultimately nitrogen and phosphorus balances on earth. Thus, to reduce the land use side effects; cost effective measurements at on and surrounding environments should be done, sustainability principle should be the basic reference point and instead of over utilization of fertilization or plant protection chemicals biological agents should be preferred.

\section{References}

Center for Sustainability and the Global Environment (SAGE) at University of Wisconsin-Madison. 2003. Global Land Use Database - Cropland extent 1992. http://www.sage.wisc.edu:16080/iamdata/, Center for Sustainability and the Global Environment (SAGE) at University of WisconsinMadison. 2003. Global Land Use Database Grazing land extent 1992. http://www.sage.wisc.edu:16080/iamdata/ Accessed on 23.07.2015. 
Compton, J.E., Boone, R.D. 2000. Long-term impacts of agriculture on soil carbon and nitrogen in New England Forests. Ecology 81(8):2314-2330

Cook, A.M., Daughton, C.G., Alexander, M. 1978. Phosphorus-containing pesticide breakdown products: quantitative utilization as phosphorus sources by bacteria. Applied And Environmental Microbiology pp:668-672.

Djodjic, F., Borling, K., Bergstrom, L. 2004. Phosphorus leaching in relation to soil type and soil phosphorus content. Journal of Environmental Quality 33(2):678-684.

Egan, H., Hammond, E. W., Thomson J. 1963. The Analysis of organo-phosphorus pesticide residues by gas chromatography. Analyst 89:175-178.

Erwin, K.L. 2009. Wetlands and global climate change: the role of wetland restoration in a changing World. Wetlands Ecology and Management 17:7184.

Hiscock, J.G., Thourot, C.S., Zhang, J. 2003. Phosphorus budget-land use relationships for the northern Lake Okeechobee watershed, Florida. Ecological Engineering 21:63-74.

Houghton, R.A. 2003. Revised estimates of the annual net flux of carbon to the atmosphere from changes in land use and land management 1850-2000. Tellus 55B:378-390.

https://myweb.rollins.edu/jsiry/WhereTheWorld $\% 2$ 0are .html Accessed on 23.07.2015.

Jarvie, H.P., Withers, P.J.A., Bowes, M.J., PalmerFelgate, E.J., Harper, D.M., Wasiak, K., Wasiak, P., Hodgkinson, R.A., Bates, A., Stoate, C., Neal, M., Wickham, H.D., Harman, S.A., Armstrong, L.K. 2010. Streamwater phosphorus and nitrogen across a gradient in rural-agricultural land use intensity. Agriculture, Ecosystems and Environment 135:238-252.

Jay S. Singh1, D.P. Singh1, A.K. Kashyap 2009. A comparative account of the microbial biomass- $\mathrm{N}$ and $\mathrm{N}$-mineralization of soils under natural forest, grassland and crop field from dry tropical region, India Plant Soil and Environment 55(6): 223-230

Knops, J. M. H., Tilman, D. 2000. Dynamics of soil nitrogen and carbon accumulation for 61 years after agricultural abandonment. Ecology, Vol. 81(1):88-98

Lilienfein, Wilcke, J.W., Ayarza, M.A., Vilela, L.S. do C., Lima, Zech, W. 2000. Chemical fractionation of phosphorus, sulphur, and molybdenum in Brazilian savannah Oxisols under different land use. Geoderma 96:31-46.

Lloret, J., Marín, A., Marín-Guirao, L. 2008. Is coastal lagoon eutrophication likely to be aggravated by global climate change? Estuarine, Coastal and Shelf Science 78:403-412.

Raaijmakers JM, Paulitz TC, Steinberg C, Alabouvette C, Moënne-Loccoz Y (2009) The rhizosphere: a playground and battlefield for soilborne pathogens and beneficial microorganisms. Plant Soil doi:10.1007/s11104-008-9568-6

Rabalais, N. N., Turner, R. E., Díaz, R. J., and Justíc, D. 2009. Global change and eutrophication of coastal waters. - ICES Journal of Marine Science, 66:1528-1537

Solomon, D., Lehmann, J., Mamo, T., Fritzsche, F., Zech, W. 2002. Phosphorus forms and dynamics as influenced by land use changes in the sub-humid Ethiopian highlands Geoderma 105:21-48.

Submitted: 11.01.2017

Accepted: 16.06.2017 